\title{
COMPARISON OF CLINICAL AND LABORATORY PROFILE OF HAART ADHERENT AND NON-ADHERENT HIVIAIDS PATIENTS IN CALABAR, NIGERIA
}

\author{
AGAM EBAJI AYUK, NDIFREKE UDONWA AND ABRAHAM GYUSE
}

(Received 28 June 2017; Revision Accepted 4 August 2017)

\begin{abstract}
Background: The burden of HIVIAIDS has reduced following sustained interventions especially with introduction of highly active antiretroviral therapy (HAART). HIVIAIDS has become a chronic condition for which adherence to therapy is of public health relevance. This study was aimed at assessing the relationship between adherence to HAART and clinical and laboratory outcomes in a tertiary centre.

Methodology: This was a cross-sectional descriptive study of three hundred and forty eight (348) respondents on HAART. Adherence was measured using an adapted adult AIDS clinical trial group (AACTG) with optimal adherence set at $\geq 95 \%$. Clinical stage, anthropometry, CD4, total lymphocyte and haemoglobin were used to monitor clinical, immunological and haematological outcome of adherence.

Result: The mean (SD) age of respondents was 34.8 (5.3) years, ranging from 18 - 68 years, with male: female ratio of $1: 1.7$. Adherence to HAART was $89.1 \%$. Non-adherent compared with adherent respondents, had marginally significantly higher proportion of WHO AIDS Stage 3 disease $(44.7 \%$ vs. $26.4 \%, p=0.05)$. Comparing baseline with current values, change in mean CD4 cell counts was significantly higher among adherent compared with non-adherent respondents (187 vs. $125, \mathrm{p}=0.00)$. Also, change in mean total lymphocyte counts was significantly higher among adherent compared with non-adherent respondents (508 vs. $314, p=0.00)$. Change in CD4 cell count significantly correlated with adherence $(t=0.15, p<0.05)$.

Conclusion: Self-reported optimal adherence significantly correlated with immunological recovery, which is a key determinant of good clinical outcome in HIV patients. Measures aimed at sustaining adherence to HAART, and regular assessment of CD4 count should be strengthened.
\end{abstract}

KEYWORDS: Adherence, CD4 count, Total lymphocyte count, Adult AIDS Clinical Trial Group

\section{INTRODUCTION}

Sub-Saharan Africa (SSA) with just over $12 \%$ of the world's population has the greatest burden of Human Immune deficiency virus (HIV) disease with 24.7 million people living with HIV, accounting for about $3 \%$ of its population (UNAIDS, 2014). There has been a general decline in new HIV infections and AIDS related death in sub-Saharan Africa with different countries having different rates of decline. Despite about $25 \%$ decline in new HIV infections in
sub-Saharan Africa, the region accounted for $70 \%$ of all new HIV infections worldwide in 2013 (UNAIDS, 2014). Nigeria being the most populous country in sub-Saharan Africa has more than 3 million people living with HIVIAIDS and the cumulative HIV- related deaths in the country is placed at 2.1 million (UNAIDS, 2014). The introduction and widespread use of highly active antiretroviral therapy (HAART) as the treatment of choice in patients with HIV infection has improved significantly the clinical condition of people living with HIVIAIDS (UNAIDS 2014; Cotton et al., 2006). The

Agam Ebaji Ayuk, Family Medicine Department, Faculty of Medicine, University of Calabar, Calabar, Nigeria.

Ndifreke Udonwa, Family Medicine Department, Faculty of Medicine, University of Calabar, Calabar, Nigeria. Abraham Gyuse, Family Medicine Department, Faculty of Medicine, University of Calabar, Calabar, Nigeria. 
introduction of HAART has transformed the perception of HIVIAIDS from a fatal incurable disease to a manageable chronic illness (Afolabi et al., 2009). Highly active antiretroviral therapy refers to the use of effective combinations of three or more antiretroviral drugs usually from two or more antiretroviral (ARV) drug classes in order to achieve the greatest suppression of viral load for the most sustained period of time (Ministry of Health Kenya, 2004; Park and Nachman, 2010).The goal of HAART is to suppress viral load in the blood to undetectable levels (levels that are no longer detectable in routine viral load assays) (UNAIDS 2014; Afolabi et., 2009). This in turn reduces the destruction of CD4 cells, reduces immune suppression and slows disease progression. Success with HAART can be seen in rising CD4 cell counts, undetectable viral loads, and clinical improvement (UNAIDS 2014; Ministry of Health Kenya, 2004).

Adherence to HAART is the second strongest predictor of progression to AIDS and death after CD4 count and remains the most important potentially alterable factor that determines treatment outcomes for patients with HIVIAIDS (Chabikuli 2010; Gross et al., 2006). Several studies in both developed and developing countries have reported that optimal adherence $(\geq 95 \%)$ correlated with a viral load decrease, CD4 cell count increase, total lymphocyte counts, haemoglobin concentrations and higher survival rates(Gross et al., 2006; Ferradini, 2006; Nieuwkerk and Oort, 2006; Gutierrez, 2006; Tang et al., 2011; Shikuma et al., 2004; Esposito et al., 2008; Quaye and Addai-Mensah, 2011).Non- adherence has also been associated with increased viral load, emerging drug resistance, increased morbidity and mortality (Brinkhof et al., 2009; Gazzola et al., 2009; Bangsberg et al., 2007).There have been mixed results of adherence rates in Africa and specifically in Nigeria with most studies reporting optimal adherence rates (Peltzer, 2010; Chabikuli 2010; Ohene and Forson, 2009; Monjok et al., 2010; Akileswaran, 2005).

This study was aimed at determining the effectiveness of HAART in terms of clinical (opportunistic infections) and laboratory outcomes (i.e, CD4 cell count, weight trends and haemoglobin concentration). These parameters are reported to be useful monitoring tools in the management of HIVIAIDS patients in resource-limited settings.

\section{METHODOLOGY}

The study was carried out over a 6 months period from March 2013 to August 2013 at the Special Treatment Clinic of the University of Calabar Teaching Hospital. It was a cross-sectional descriptive study with a total of 348subjects who were on HAART for at least 6 months. The sample size was calculated using the Leslie and Kish statistical formula for cross sectional qualitative surveys $\left[n=Z^{2} P(1-P) / d^{2}\right]$ (Charan and Biswas, 2013). Ethical clearance was obtained from the Health Research Ethics Committee of University of Calabar Teaching Hospital. Informed consent was obtained from respondents.

Adherence to HAART was measured using self-reported adapted AACTG (Chesney et al., 2000; Reynolds et al., 2007). This is validated for resource limited settings. Adherence was calculated as the percentage of number of doses taken divided by the number of prescribed doses over the preceding four days. Adherence was dichotomised to $\geq 95 \%$ classified as "adherent" and $<95 \%$ classified as "non adherent" (Ministry of Health Kenya, 2004; World Health Organization, 2006).

Participants were examined for any clinical condition listed in the World Health Organization (WHO) clinical staging guidelines, in accordance with the clinical diagnosis criteria (presumptive diagnosis) (World Health Organization, 2006).

Laboratory parameters: CD4 count, haemoglobin level and total lymphocyte count were obtained as baseline values at initiation of HAART and current values as at the time of study.CD4+ T-cell count was done using the Cyflow Automated CD4 counter (model-Cyflow SL3). Results were expressed in a histogram (CD4+ cells/ $\mu$ l). Haematological assay was done using Sysmex Haematology Automated cell counter (model-KX-21N) haemoglobin (gram per decilitre) and lymphocyte count ((number of cells $\times 10^{9}$ per litre).

Body Mass Index (BMI) was calculated using participant's weight and height with the mathematical equation: weight (in kilograms) divided by height squared and the result expressed in kilograms per meter squared. Weights were recorded in kilogram (kg) using analog weighing scale (model - HANA) and read to the nearest $0.1 \mathrm{~kg}$. Height was measured in meters using a stadiometer (SECA, model-220).

\section{RESULTS}

\section{Socio-demographic characteristics}

Data was obtained from three hundred and forty eight (348) respondents, with mean (SD) age of 34.8 (5.3) years, ranging from $18-68$ years. The male: female ratio was $1: 1.7$, with the males being generally older, with a mean (SD) age of $43.8(7.3)$ years compared to females with mean (SD) age of 36.6 (5.4) years $(p=0.00)$. The Mean (SD) duration on ARV was 45.6 (22.2) months, ranging from $6-133$ months. The commonest marital status was being married (173, $49.7 \%$ ), and most respondents had at least secondary 
level of education (284, 81.6\%), and were Pentecostal Christians, with no significant difference in these socio demographic characteristics comparing male and females $(p>0.05$, table 1$)$.

\section{Adherence to HAART measured with AACTG}

Three hundred and ten $(89.1 \%)$ had $\geq 95 \%$ adherence to HAART using AACTG. Also, mean adherence level was $96.1 \pm 19.7$
Relationship between clinical parameters and adherence to HAART

Using the AACTG instrument, 185 (59.7\%), 43 $(13.9 \%)$, and $82(26.4 \%)$ of adherent respondents, had stage 1,2 and 3 HIV disease, respectively. However, 16 (42.1\%), 5 (13.2\%), and 17 (44.7\%) of non-adherent respondents had stage 1, 2 and 3 HIV disease, respectively. Though stage 3 disease was proportionally commoner among non-adherent compared with adherent respondents, the difference was marginally statistically significant $(p=0.05$, table 2).

Table 1: Socio-demographic characteristics of respondents $(\mathrm{N}=348)$

\begin{tabular}{|c|c|c|c|c|c|}
\hline Variable & $\begin{array}{l}\text { Male } \quad \text { n } \\
(\%)\end{array}$ & $\begin{array}{l}\text { Female } \\
\text { n (\%) }\end{array}$ & \begin{tabular}{|l|} 
Total \\
n (100\%)
\end{tabular} & $\begin{array}{l}\text { Chi- } \\
\text { Square }\end{array}$ & P-value \\
\hline \multicolumn{6}{|l|}{ Age Group } \\
\hline$\leq 39$ & $41(20.1)$ & $163(79.9$ & $204(100)$ & \multirow[t]{3}{*}{61.0} & \multirow[t]{3}{*}{0.00} \\
\hline$\overline{40-59}$ & $79(61.7)$ & $49(38.3)$ & $128(100)$ & & \\
\hline$>59$ & $9(56.3)$ & $7(43.7)$ & $16(100)$ & & \\
\hline \multicolumn{6}{|l|}{ Marital Status } \\
\hline Married & $80(46.2)$ & $93(53.8)$ & $173(100)$ & \multirow{5}{*}{$\begin{array}{l}\text { Fisher's } \\
\text { Exact }\end{array}$} & \multirow[t]{5}{*}{0.00} \\
\hline Single & $41(28.9)$ & $101(71.1)$ & $142(100)$ & & \\
\hline Divorced & $3(42.9)$ & $4(57.1)$ & $7(100)$ & & \\
\hline Separated & $3(75.0)$ & $1(25.0)$ & $4(100)$ & & \\
\hline Widowed & $2(9.1)$ & $20(90.9)$ & $22(100)$ & & \\
\hline \multicolumn{6}{|l|}{ Educ. Level } \\
\hline No formal & $1(15.3)$ & $6(85.7)$ & $7(100)$ & \multirow{5}{*}{$\begin{array}{l}\text { Fisher's } \\
\text { Exact }\end{array}$} & \multirow[t]{5}{*}{0.64} \\
\hline Primary & $19(36.5)$ & $33(63.5)$ & $52(100)$ & & \\
\hline Secondary & $53(35.1)$ & $98(64.9)$ & $151(100)$ & & \\
\hline Tertiary & $54(40.6)$ & $79(59.4)$ & $133(100)$ & & \\
\hline Post-graduate & $2(40.0)$ & $3(60.0)$ & $5(100)$ & & \\
\hline \multicolumn{6}{|l|}{ Religion } \\
\hline Roman Catholic & $27(39.1)$ & $42(60.9)$ & $69(100)$ & \multirow{5}{*}{$\begin{array}{l}\text { Fisher's } \\
\text { Exact }\end{array}$} & \multirow[t]{5}{*}{0.48} \\
\hline Orthodox & $9(25.0)$ & $27(25.0)$ & $36(100)$ & & \\
\hline Pentecostal & $81(39.1)$ & $126(60.9)$ & $207(100)$ & & \\
\hline Other denom. & $12(34.3)$ & $23(65.7)$ & $35(100)$ & & \\
\hline Islam & $0(0.0)$ & $1(100)$ & $1(100)$ & & \\
\hline \multicolumn{6}{|l|}{ Occupation } \\
\hline Business & $54(36.5)$ & $94(63.5)$ & $148(100)$ & \multirow{7}{*}{$\begin{array}{l}\text { Fisher's } \\
\text { Exact }\end{array}$} & \multirow[t]{7}{*}{0.07} \\
\hline Civil servant & $30(39.0)$ & $47(61.0)$ & $77(100)$ & & \\
\hline Unemployed & $17(35.4)$ & $31(64.6)$ & $48(100)$ & & \\
\hline Trading & $12(38.7)$ & $19(61.3)$ & $31(100)$ & & \\
\hline Student & $2(10.0)$ & $18(90.0)$ & $20(100)$ & & \\
\hline Farming & $8(53.3)$ & $7(46.7)$ & $15(100)$ & & \\
\hline Others & $6(66.7)$ & $3(33.3)$ & $9(100)$ & & \\
\hline
\end{tabular}


Table 2: Relationship between clinical parameters and HAART adherence status $(\mathrm{N}=348)$

\begin{tabular}{|c|c|c|c|c|c|c|}
\hline \multirow{2}{*}{$\begin{array}{l}\text { Adherence } \\
\text { (AACTG) }\end{array}$} & \multicolumn{3}{|c|}{ WHO AIDS Clinical Stage } & \multirow{2}{*}{$\begin{array}{l}\text { Total } \\
\mathrm{n}(100 \%)\end{array}$} & \multirow{2}{*}{$\begin{array}{l}\text { Chi- } \\
\text { Square }\end{array}$} & \multirow[t]{2}{*}{ p-value } \\
\hline & $\begin{array}{l}\text { Stage } 1 \text { n } \\
(\%)\end{array}$ & $\begin{array}{ll}\text { Stage } & 2 \\
\mathrm{n}(\%) & \end{array}$ & $\begin{array}{ll}\text { Stage } & 3 \\
\text { n (\%) } & \end{array}$ & & & \\
\hline Adherent & $185(59.7)$ & $43(13.9)$ & $82(26.4)$ & $310(100)$ & \multirow[t]{3}{*}{5.8} & \multirow[t]{3}{*}{0.05} \\
\hline Non-adherent & $16(42.1)$ & $5(13.2)$ & $17(44.7)$ & $38(100)$ & & \\
\hline Total & $201(57.8)$ & $48(13.8)$ & $99(28.4)$ & $348(100)$ & & \\
\hline
\end{tabular}

Comparison of mean anthropometric and laboratory parameters between adherent and non-adherent respondents using AACTG instrument

There was no difference between mean BMl for adherent respondents (24.5) and that of non-adherent respondents (24.1) using the AACTG instrument. Similarly, comparing adherent and non-adherent respondents, there was no significant difference in
BMI change (2.4 vs. 2.2), CD4 cell count (451 vs. 421), haemoglobin concentration (12.9 vs. 12.0), change in haemoglobin concentration (1.7 vs. 1.5), and total lymphocyte count $(2,247$ vs. 2,109$)$. However, change in CD4 cell counts (187 vs.125) and change in total lymphocyte count (508 vs 314 ), were significantly different comparing adherent and nonadherent

respectively.

Table 3: Comparison of anthropometric and laboratory parameters between adherent and non-adherent respondents using AACTG instrument $(\mathrm{N}=348)$

\begin{tabular}{|l|l|l|l|l|}
\hline Variable & $\begin{array}{l}\text { Adherent } \\
(\mathrm{n}=310) \\
\text { mean }+\mathrm{SD}\end{array}$ & $\begin{array}{l}\text { Non-adherent } \\
(\mathrm{n}=38) \quad \text { mean } \\
\text { + SD }\end{array}$ & t-test & -value \\
\hline Baseline BMI & $22.8 \pm 2.7$ & $22.3 \pm 1.1$ & 2.13 & 0.98 \\
\hline Current BMI & $24.5 \pm 3.1$ & $24.1 \pm 4.0$ & 0.60 & 0.72 \\
\hline BMI Change & $2.4 \pm 0.3$ & $2.2 \pm 0.2$ & 0.55 & 0.50 \\
\hline Baseline CD4 Cell count & $306 \pm 173$ & $293 \pm 138$ & 0.53 & 0.70 \\
\hline Current CD4 Cell count & $451 \pm 211$ & $421 \pm 194$ & 0.90 & 0.81 \\
\hline Change in CD4 Cell count & $187 \pm 91$ & $125 \pm 51$ & 6.4 & 0.00 \\
\hline Baseline Haemoglobin conc. & $11.3 \pm 3.5$ & $10.7 \pm 2.4$ & 1.37 & 0.91 \\
\hline Current Haemoglobin conc. & $12.9 \pm 6.8$ & $12.0 \pm 1.3$ & 2.0 & 0.89 \\
\hline Change in Haemoglobin conc. & $1.7 \pm 1.2$ & $1.5 \pm 0.8$ & 0.68 & 0.75 \\
\hline Baseline Total Lymphocyte count & $1,671 \pm 455$ & $1,749 \pm 393$ & 1.13 & 0.13 \\
\hline Current Total Lymphocyte count & $2,247 \pm 633$ & $2,109 \pm 541$ & 1.5 & 0.15 \\
\hline Change in Total Lymph. Count & $508 \pm 194$ & $314 \pm 133$ & 8.0 & 0.00 \\
\hline
\end{tabular}

There was weak and non-significant positive correlation between adherence level, and change in $\mathrm{BMI}$, change in haemoglobin concentration and change in total lymphocyte count $(p>0.05)$. However, positive correlation between level of adherence and change in CD4 count, was found to be statistically significant $\quad(p=0.04) \quad($ Table $4, \quad$ Fig. 1). 
Table 4: Correlation between anthropometric/laboratory outcomes and level of adherence to HAART (N=348)

\begin{tabular}{|l|l|l|}
\hline Variable & $\begin{array}{l}\text { Pearson } \\
\text { coefficient }\end{array}$ & p-value \\
\hline Change in BMI & 0.05 & 0.35 \\
\hline Change in CD4 Cell count & 0.15 & 0.04 \\
\hline Change in Haemoglobin concentration & 0.04 & 0.42 \\
\hline Change in Total Lymphocyte count & 0.07 & 0.06 \\
\hline
\end{tabular}

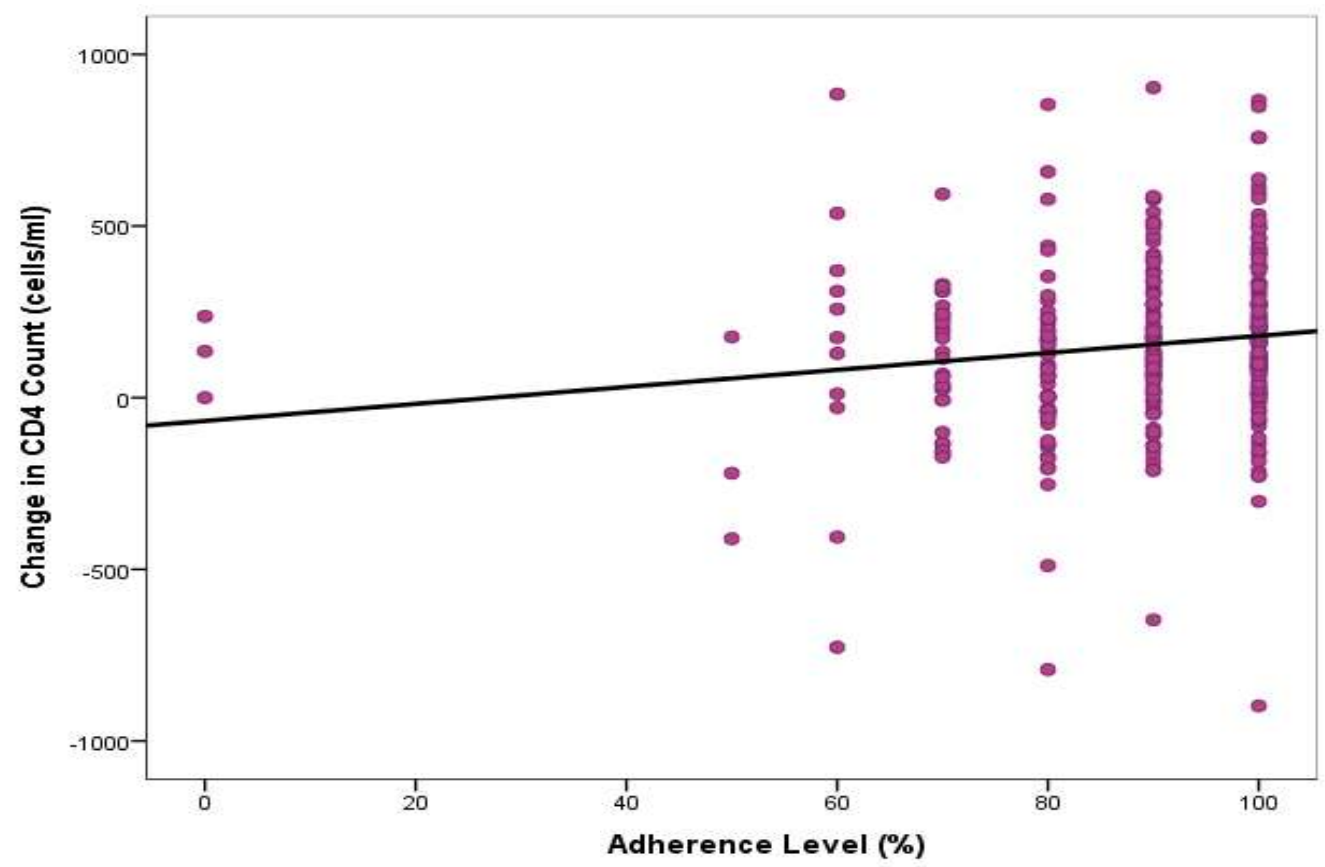

Figure 1: Scatter plot showing correlation between change in CD4 count and level of adherence $(\mathrm{N}=348)$

\section{DISCUSSION}

This facility-based study found statistically significant higher proportion of female respondents (male: female ratio of $1: 1.7$ ) who were living with HIV $(p<0.05)$ and on HAART $(p<0.05)$. This finding corroborates reports on sub-Saharan Africa that revealed that there were more females than males living with HIV (UNAIDS, 2014; Bello, 2011). Similarly, Bello and colleagues, in their study in llorin, reported that women are 2 to 4 times more vulnerable to HIV transmission than men (Bello, 2011). This may be due to biological vulnerability of the female genitalia with a larger surface area, the female being the recipient of semen and is prone to micro trauma during sexual activity, early exposure to sexual activity and inequality in relationships (UNAIDS, 2014; National Agency for the Control of AIDS, 2011).

The AACTG instrument identified $89.1 \%$ adherent respondents. Studies in various settings have reported adherence rates similar to findings in the present study (Chkhartishvili, et al., 2014; Kleinman, et al., 2014; Fisher et al., 2011).In this study, proportionally more adherent respondents were found to have earlier stage disease (stage 1), compared with late disease (stage 3 ). This was found to be statistically significant $(p<0.05)$. Similar findings have been reported by studies in diverse clinical settings in developed and developing countries (Gross et al., 2006; Ferradini, et al., 2006; Akileswaran, 2005). Akileswaran, et al, in a systematic review of 
HAART use in Africa reported improved clinical outcomes with optimal adherence in most studies reviewed (Akileswaran, 2005). This is in tune with the established role of HAART in significantly reducing viral load and increasing CD4 cell count, and thereby minimizing damage or insult to essential body cells and tissues, therefore retarding disease progression with improvement or restoration of immunity against opportunistic infections (Gross et al., 2006; Ferradini, 2006; Nieuwkerk and Oort, 2006; Gutierrez, 2006; Crum et al., 2006; Hart et al., 2010). The improved clinical outcome of adherent subjects in the present study may have been due to the fact that the cohorts were taking the medicines as revealed by the high rate of adherence and the effectiveness of the regimen. These findings support the established fact of improvement in clinical condition of patients on HAART over time, as the mean duration on HAART for the cohort was 45.6 months (range from 6-133 months), which is enough time for evidence of clinical improvement (Ferradini, 2006). Furthermore, at this early clinical stage, development of opportunistic infections will be minimal, thus reducing HIV-related mortality and improving survival among the cohort (World Health Organization, 2010; Gutierrez et al., 2006). Using AACTG adherence measure, $26.4 \%$ of adherent respondents were stage 3 disease, and stage 3 disease is reported to independently predict HIV-related mortality (World Health Organization, 2010). Systematic reviews have reported similar findings of emergence of opportunistic infections despite optimal adherence attributable to drug resistance (Akileswaran, 2005). The possible reasons for the finding of stage 3 disease despite claim of optimal adherence in the present study may be due to respondents not taking the medications as claimed, advanced clinical stage at beginning of HAART, drug resistance and nutritional deficiencies among the cohorts.

In this study, the initiation of HAART was associated with mean body weight increases of $3.6 \mathrm{~kg}$ and mean body mass index increases of $1.3 \mathrm{~kg} / \mathrm{m}^{2}$. The mean BMI was marginally higher among adherent compared with non-adherent respondents, but there was no statistical significance. These increases in weight and BMI in this study are consistent with those reported in the literature (Shikuma et al., 2004; Esposito et al., 2008; Quaye and AddaiMensah).Studies have reported relationship between HAART induced decrease in virus burden, increased CD4 cell count and increased mean weight and BMI (Shikuma et al., 2004; Esposito et al., 2008). In this study, it was found that there was a mean increase in CD4 cell count and mean weight and BMI increases from initiation of HAART, indicating increase in weight is related to viral suppression and immunological response. Viral load was not assessed because the equipment was not available in the centre as at the time the study was carried out. The decrease in opportunistic infections, decreased malabsorption and improved nutritional status may be contributing factors to weight and BMI increase in the study. The finding that a large proportion (48.7\%) of the study subjects had BMI above the upper limit of normal range is cause for concern because of the known risk of overweight and obesity in the general population. These risks include diabetes mellitus, hypertension and dyslipidaemia (Esposito, 2008). This issue of overweight and obesity needs attention and studies are needed to determine their significance in HIVinfected population in Nigeria.

Immunological response to HAART assessed by CD4 cell counts and total lymphocyte counts were higher and statistically significant among adherent compared with non-adherent cohorts $(p<0.05)$. Also, female respondents had higher and statistically significant mean levels of CD4 cells compared to male respondents and there was also significant correlation between change CD4 cell counts and adherence $(p=0.04)$. These findings are consistent with other studies that have explored similar relationship (Gross et al., 2008; Ferradini et al., 2006; Nieuwkerk and Oort, 2005; Wood et al., 2006). The current study confirms what other studies have found that selfreported medication adherence is a strong predictor of immunologic outcome (Gross et al., 2006; Nieuwkerk and Oort, 2005; Crum et al., 2006). Other methods of measuring adherence such as the use of MEMS caps, may allow for greater precision in measurement; however, these methods also have draw backs including greater cost, inconvenience, practicability in resource-poor settings and confidentiality concerns (Ministry of Health, Kenya, 2004; Fletcher et al., 2005). On the other hand self-reporting offers the advantage of low cost and ease of administration, in addition to revealing the reasons why doses were missed. Optimal adherence leads to suppression of viral replication, thus reducing likelihood for HIV mutations that could lead to drug resistant viral strains. Also, optimal adherence prevents further destruction of the cellular immune system with consequent increase in the level of CD4 cells and reduction in development of opportunistic infections (Migueles and Connors, 2010).

Haemoglobin concentration in the present study was not found to be significantly associated with levels of adherence to HAART ( $p>0.05)$. This was at variance with findings from prospective studies by Tang et al, and Odunukwe and colleagues that reported significant increase in haemoglobin 
concentration with adherence and CD4 cell count (Odunukwe et al., 2005; Tang et al., 2011).This variance may have been due to the presence of other mediating factors, including nutritional deficiencies and undercurrent illness (Tang et al., 2011).

\section{CONCLUSION}

Self-reported optimal adherence significantly correlated with changes in CD4 cell count, as hallmark of immunological recovery and determinant of clinical outcome. Continuous counseling, regular CD4 count assessment, and other measures aimed at improving adherence to HAART are therefore recommended. Therefore, measures aimed at ensuring optimal adherence should be reinforced.

\section{REFERENCES}

Joint United Nations Programme on HIVIAIDS. UNAIDS 2014 Report. Geneva, Switzerland: UNAIDS; 2014. p. 1-2. Accessed on January 20, 2015.

Cotton, S., Puchalski, C. M., Sherman, S. N., Mrus, J. M., Peterman, A. H and Feinberg, J., 2006. Spirituality and religion in patients with HIVIAIDS. Journal of general internal medicine. 21(S5):S5-S13.

Afolabi, M. O., ljadunola, K. T., Fatusi, A. O and Olasode O. A., 2009. Determinants of adherence to antiretroviral drugs among people living with HIVIAIDS in the Ife-ljesa zone of Osun State, Nigeria: Original research. African Primary Health Care and Family Medicine. 1, (1): 1-6.

Ministry of Health, Kenya. Adherence to Antiretroviral Therapy in Adults: A Guide for Trainers. Mombasa, Ministry of Health; 2004. p. xi. Available at http://www.popcouncil.org/pdf. Accessed October 21, 2011.

Park, J and Nachman, S., 2010. The link between religion and HAART adherence in pediatric HIV patients. AIDS Care. 22(5):556-61.

Chabikuli, N. O., Datonye, D. O., Nachega, J and Ansong, D., 2010. Adherence to antiretroviral therapy, virologic failure and workload at the Rustenburg Provincial Hospital. South African Family Practice. 52, (4):

Gross, R., Yip, B., Lo Re V, 3rd, Wood, E., Alexander, C. S., Harrigan, P. R, et al., 2006. A simple, dynamic measure of antiretroviral therapy adherence predicts failure to maintain HIV-1 suppression. J Infect Dis. Oct 15;194, (8):1108-14.

Ferradini, L., Jeannin, A., Pinoges, L., Izopet, J., Odhiambo, D and Mankhambo, L., 2006. Scaling up of highly active antiretroviral therapy in a rural district of Malawi: an effectiveness assessment. The Lancet.367(9519):1335-42.

Nieuwkerk, P. T and Oort, F. J., 2005. Self-reported adherence to antiretroviral therapy for HIV-1 infection and virologic treatment response: a meta-analysis. JAIDS Journal of Acquired Immune Deficiency Syndromes.38(4):445-8.

Gutierrez, F., Padilla, S., Masia, M., Iribarren, J. A., Moreno, S and Viciana, P. et al., 2006. Clinical outcome of HIV-infected patients with sustained virologic response to antiretroviral therapy: long-term follow-up of a multicenter cohort. PLoS One.1:e89.

Tang, L., Jin, C., Wu, L., Brockmeyer, N., Potthoff, A and Wu, N., 2011. The impact of highly active antiretroviral treatment on the blood profiles of patients with acquired immune deficiency syndrome. Journal of International Medical Research.39(4):1520-8.

Shikuma, C., Zackin, R., Sattler, F., Mildvan, D., Nyangweso, P and Alston, B. et al., 2004. Changes in weight and lean body mass during highly active antiretroviral therapy. Clinical Infectious Diseases.39(8):1223-30.

Esposito, F., Coutsoudis, A., Visser, J and Kindra, G.,

2008. Changes in body composition and other anthropometric measures of female subjects on highly active antiretroviral therapy (HAART): a pilot study in Kwazulu-Natal, South Africa. Southern African Journal of HIV Medicine. 9(4):36-42.

Quaye, W and Addai-Mensah, A., 2011. Prevalence of anaemia and immunological markers among Ghanaian HAART-naïve HIV-patients and those on HAART. African health sciences. 11(1).

Brinkhof, M. W., Pujades-Rodriguez, M and Egger, M., 2009. Mortality of patients lost to follow-up in antiretroviral treatment programmes in resource-limited settings: systematic review and meta-analysis. PLoS One. 4(6):e5790. 
Gazzola, L., Tincati, C., Bellistré, G. M., Monforte AdA and Marchetti, G., 2009. The absence of CD4+ T cell count recovery despite receipt of virologically suppressive highly active antiretroviral therapy: clinical risk, immunological gaps, and therapeutic options. Clinical Infectious Diseases. 48(3):328-37.

Bangsberg, D. R., Kroetz, D. L and Deeks, S. G., 2007. Adherence-resistance relationships to combination HIV antiretroviral therapy. Curr HIVIAIDS Rep. May;4(2):65-72.

Peltzer, K., Friend-du Preez, N., Ramlagan, $\mathrm{S}$ and Anderson, J., 2010. Antiretroviral treatment adherence among HIV patients in KwaZulu-Natal, South Africa. BMC public health. 10:111.

Ohene, S and Forson, E., 2009. Care of patients on anti-retroviral therapy in kumasi metropolis. Ghana Med J. Dec;43(4):144-9.

Monjok, E., Smesny, A., Okokon, I. B., Mgbere, O and Essien, E. J., 2010. Adherence to antiretroviral therapy in Nigeria: an overview of research studies and implications for policy and practice. HIV AIDS (Auckl). 2:69-76.

Akileswaran, C., Lurie, M. N., Flanigan, T. P and Mayer, K. H., 2005. Lessons learned from use of highly active antiretroviral therapy in Africa. Clinical Infectious Diseases. 41(3):376-85.

Charan, J and Biswas, T., 2013. How to Calculate Sample Size for Different Study Designs in Medical Research? Indian J Psychol Med [Internet]. 35(2):121-6. Available from: http://www.pubmedcentral.nih.gov/articlerend er.fcgi?artid=3775042\&tool=pmcentrez\&rende rtype $=$ abstract

Chesney, M. A., Ickovics, J. R., Chambers, D. B., Gifford, A. L., Neidig, J and Zwickl, B. et al., 2000. Self-reported adherence to antiretroviral medications among participants in HIV clinical trials: the AACTG adherence instruments. Patient Care Committee \& Adherence Working Group of the Outcomes Committee of the Adult AIDS Clinical Trials Group (AACTG). AIDS Care. Jun;12(3):255-66.

Reynolds, N. R., Sun, J., Nagaraja, H. N., Gifford, A. L., Wu, A. W and Chesney, M. A., 2007. Optimizing measurement of self-reported adherence with the ACTG Adherence Questionnaire: a cross- protocol analysis. JAIDS Journal of Acquired Immune Deficiency Syndromes. 46(4):402-9.

World Health Organisation., 2006. Case Definitions of HIV for Surveillance and Revised Clinical Staging and Immunological Classification of HIV Related Disease in Adults and Children. WHO; p. 13.

Bello, S., 2011. HIVIAIDS patients' adherence to antiretroviral therapy in Sobi specialist hospital, Ilorin, Nigeria. Global Journal of Medical Research. 11(2).

National Agency for the Control of AIDS. Fact sheet 2011: update on the HIV epidemic and response in Nigeria. NACA 2011; 2011. p. 7-8. Available at http://www.naca.gov.ng. Accessed November 27, 2011.

Chkhartishvili, N., Rukhadze, N., Svanidze, M., Sharvadze, L., Dehovitz, J. A and Tsertsvadze, T. et al., 2014. Evaluation of multiple measures of antiretroviral adherence in the Eastern European country of Georgia. Journal of the International AIDS Society.17(1):

Kleinman, N. J., Manhart, L. E., Mohanraj, R., Kumar, S., Jeyaseelan, L and Rao, D. et al., 2014. Antiretroviral therapy adherence measurement in non-clinical settings in South India. AIDS Care. (ahead-of-print):1-7.

Fisher, J. D., Amico, K. R., Fisher, W. A., Cornman, D. H., Shuper, P. A and Trayling, C. et al., 2011. Computer-based intervention in HIV clinical care setting improves antiretroviral adherence: the LifeWindows Project. AIDS and Behavior. 15(8):1635-46.

Crum, N. F., Riffenburgh, R. H., Wegner, S., Agan, B. K., Tasker, S. A and Spooner, K. M. et al., 2006. Comparisons of causes of death and mortality rates among HIV-infected persons: analysis of the pre-, early, and late HAART (highly active antiretroviral therapy) eras. J Acquir Immune Defic Syndr. Feb 1;41(2):194-200.

Hart, J. E., Jeon, C. Y., Ivers, L. C., Behforouz, H. L., Caldas, A and Drobac, P. C. et al., 2010. Effect of directly observed therapy for highly active antiretroviral therapy on virologic, immunologic, and adherence outcomes: a meta-analysis and systematic review. Journal 
of acquired immune deficiency syndromes (1999).54(2):167.

World Health Organization., 2010. Antiretroviral therapy for HIV infection in adults and adolescents: recommendations for a public health approach-2010 revision..p.24-40

Wood, E., Hogg, R. S., Yip, B., Moore, D., Harrigan, P. R and Montaner, J. S., 2006. Impact of baseline viral load and adherence on survival of HIVinfected adults with baseline CD4 cell counts $\geq$ 200 cells/ $\mu$ l. AIDS. 20(8):1117-23.

Fletcher, C. V., Testa, M. A., Brundage, R. C., Chesney, M. A., Haubrich, R and Acosta, E. P. et al., 2005. Four measures of antiretroviral medication adherence and virologic response in AIDS clinical trials group study 359. JAIDS Journal of Acquired Immune Deficiency Syndromes. 40(3):301-6.

Migueles, S. A and Connors, M., 2010. Long-term nonprogressive disease among untreated HIV-infected individuals: clinical implications of understanding immune control of HIV. JAMA. 304(2):194-201.

Odunukwe, N., Idigbe, O., Kanki, P., Adewole, T., Onwujekwe, D and Audu, R. et al., 2005. Haematological and biochemical response to treatment of HIV-1 infection with a combination of nevirapine+ stavudine+ lamivudine in Lagos Nigeria. Turkish Journal of Haematology. 22(3):125-31. 